\title{
Phytochemical Investigation of Tradescantia Albiflora and Anti-Inflammatory Butenolide Derivatives
}

\author{
Ping-Chen Tu ${ }^{1}$, Han-Chun Tseng ${ }^{2}$, Yu-Chia Liang ${ }^{3}$, Guan-Jhong Huang ${ }^{3}$, Te-Ling Lu ${ }^{4,+}$, \\ Tzong-Fu Kuo ${ }^{5,+}$ and Yueh-Hsiung Kuo ${ }^{3,6,7, * \mathbb{D}}$ \\ 1 The Ph.D. Program for Cancer Biology and Drug Discovery, China Medical University and Academia Sinica, \\ Taichung 404, Taiwan; pingchen.tu@gmail.com \\ 2 Department of Chemistry, National Taiwan University, Taipei 106, Taiwan; hcts97@gmail.com \\ 3 Department of Chinese Pharmaceutical Sciences and Chinese Medicine Resources, China Medical University, \\ Taichung 404, Taiwan; allen1987323@yahoo.com.tw (Y.-C.L.); gjhuang@mail.cmu.edu.tw (G.H.) \\ 4 School of Pharmacy, China Medical University, Taichung 404, Taiwan; lutl@mail.cmu.edu.tw \\ 5 Department of Post-Baccalaureate Veterinary Medicine, Asia University, Taichung 413, Taiwan; \\ tzongfu@asia.edu.tw \\ 6 Department of Biotechnology, Asia University, Taichung 413, Taiwan \\ 7 Chinese Medicine Research Center, China Medical University, Taichung 404, Taiwan \\ * Correspondence: kuoyh@mail.cmu.edu.tw; Tel.: +886-4-2205-3366 (ext.5709) \\ + The authors contributed equally to this work.
}

Academic Editor: Maria da Graça Costa G. Miguel

Received: 28 August 2019; Accepted: 12 September 2019; Published: 13 September 2019

\begin{abstract}
Phytochemical investigation of the whole plant of Tradescantia albiflora Kunth led to the isolation and characterization of a butanolide, rosmarinosin B (1), that was isolated from natural sources for the first time, a new butenolide, 5-O-acetyl bracteanolide A (2), and a new apocarotenoid, 2 $\beta$-hydroxyisololiolide (11), together with 25 known compounds (compounds 3-10 and 12-28). The structures of the new compounds were elucidated by analysis of their spectroscopic data, including MS, 1D, and 2D NMR experiments, and comparison with literature data of known compounds. Furthermore, four butenolides $\mathbf{4 a - 4 d}$ were synthesized as novel derivatives of bracteanolide A. The isolates and the synthesized derivatives were evaluated for their preliminary anti-inflammatory activity against lipopolysaccharide (LPS)-stimulated nitric oxide (NO) production in RAW 264.7 cells. Among them, the synthesized butenolide derivative $n$-butyl bracteanolide A (4d) showed enhanced $\mathrm{NO}$ inhibitory activity compared to the original compound, with an $\mathrm{IC}_{50}$ value of $4.32 \pm 0.09 \mu \mathrm{g} / \mathrm{mL}$.
\end{abstract}

Keywords: Tradescantia albiflora; butenolides; anti-inflammatory activity

\section{Introduction}

Tradescantia albiflora Kunth (Commelinaceae) is native to tropical rainforests. It has been used as a traditional medicine for treating hyperuricemia and gout in Taiwan. Previous research described the inhibitory activity against xanthine oxidase $(\mathrm{XO})$, which plays a central role in metabolic disorders such as hyperuricemia and gout, of the methanol extract and compounds isolated from the leaves of T. albiflora [1]. However, none of the isolated compounds showed significant inhibitory activity.

Our continuing investigation on the bioactive compounds from T. albiflora has now led to the extraction, purification, and structural elucidation of three new naturally occurring compounds, together with 25 known compounds. The butenolide bracteanolide A (4) was the most abundant compound among the isolates, and it has been reported to show inhibitory ability against lipopolysaccharide (LPS)-stimulated nitric oxide (NO) production in RAW 264.7 cells. This inhibition was associated with its selective suppression on inducible NO synthase (iNOS) induction [2], indicating its potential to 
treat inflammatory diseases caused by NO production. For this reason, bracteanolide A (4) was used as a starting material for the preparation of butenolide derivatives. In addition, the isolates and four newly synthesized derivatives were evaluated for their preliminary anti-inflammatory activity against LPS-stimulated NO production in RAW 264.7 cells.

\section{Results and Discussion}

Phytochemical investigation of the whole plants of T. albiflora Kunth led to the isolation and characterization of three new compounds and 25 known compounds, which were identified by comparison with literature spectroscopic data and determined as 4-(3', $4^{\prime}$-dihydroxyphenyl)furan-2(5H)- one (3) [3], bracteanolide A (4) [2], bracteanolide B (5) [2], methyl 3,4-dihydroxybenzoate (6) [4], hydroxytyrosol (7) [5], 1-(3,4-dihydroxyphenyl)-2-hydroxyethan-1-one (8) [5], ( \pm )-tradescantin (9) [3], tricin (10) [6], isololiolide (12) [7], loliolide (13) [8], (3R)-3-hydroxy- $\beta$-ionone (14) [9], (6R,7E,9R)-9-hydroxy-4,7megastigmadien-3-one (15) [10], (E)-3,5,5-trimethyl-4-(3-oxobut-1-en-1-yl)cyclohex-2-enone (16) [11], (S)-dehydrovomifoliol (17) [12], N-trans-feruloyltyramine (18) [13], N-trans-feruloyl-3-methoxytyramine (19) [13], sitosterol (20) [14], stigmasterol (21) [14], 7-ketositosterol (22) [15], 7-ketostigmasterol (23) [15], 7 $\beta$-hydroxysitosterol (24) [15], schottenol (25) [14], ergosterol peroxide (26) [16], 24,25-dihydrocimicifugenol (27) [17], 3-epicyclomusalenol (28) [17] (Figure 1).

Compound 1 was obtained as a colorless amorphous solid with $[\alpha]_{D}^{25}-13.5$, and its high resolution electrospray ionization mass spectrometry (HRESIMS) data determined the molecular formula as $\mathrm{C}_{10} \mathrm{H}_{10} \mathrm{O}_{4}\left(m / z\right.$ 217.0464, assigned as $\left.\mathrm{C}_{10} \mathrm{H}_{10} \mathrm{O}_{4} \mathrm{Na}\right)$ indicating six degrees of unsaturation. The IR spectrum displayed the presence of hydroxyl $\left(3312 \mathrm{~cm}^{-1}\right), \gamma$-lactone $\left(1758 \mathrm{~cm}^{-1}\right)$, and aromatic $(1607$, $1526 \mathrm{~cm}^{-1}$ ) functionalities.

The ${ }^{1} \mathrm{H}-\mathrm{NMR}$ spectrum (Table 1 ) displayed signals characteristic of a trisubstituted benzene ring indicated by an ABX-pattern for three aromatic protons $\left[\delta_{\mathrm{H}} 6.73(\mathrm{~d}, J=8.4 \mathrm{~Hz}), 6.61(\mathrm{dd}, J=8.4\right.$, $2.0 \mathrm{~Hz})$, and $6.71(\mathrm{~d}, J=2.0 \mathrm{~Hz})$ ] and a butanolide moiety deduced from the following spectroscopic data: one pair of oxymethylene protons $\left[\delta_{\mathrm{H}} 4.62(\mathrm{t}, J=8.0 \mathrm{~Hz})\right.$ and $\left.4.20(\mathrm{t}, J=8.0 \mathrm{~Hz})\right]$, one pair of lactone methylene protons $\left[\delta_{\mathrm{H}} 2.86(\mathrm{dd}, J=17.4,8.6 \mathrm{~Hz})\right.$ and $\left.2.62(\mathrm{dd}, J=17.4,8.9 \mathrm{~Hz})\right]$, and one methine proton $\left(\delta_{\mathrm{H}} 3.68, \mathrm{~m}\right)$, together with the IR peak at $v_{\max } 1758 \mathrm{~cm}^{-1}$. The HMBC correlations from $\mathrm{H}-3 \mathrm{a}, \mathrm{H}-3 \mathrm{~b}, \mathrm{H}-4, \mathrm{H}-5 \mathrm{a}$, and $\mathrm{H}-5 \mathrm{~b}$ to $\mathrm{C}-1^{\prime}\left(\delta_{\mathrm{C}} 133.0\right)$ indicated that the butanolide functionality was attached on $\mathrm{C}-1^{\prime}$. This assignment was confirmed by the deshielded signal of benzylic proton at $\delta_{\mathrm{H}}$ $3.68(\mathrm{H}-4)$. According to the overall specific rotation, 1D, and 2D NMR, compound 1 was determined as rosmarinosin $B$ with a $3 R$ configuration, which was previously obtained as an artificial compound by gamma irradiation-assisted degradation of rosmarinic acid and exhibited moderately enhanced anti-adipogenic properties in 3T3-L1 cells than the original compound [18]. It was isolated from the natural sources for the first time. 
<smiles></smiles>

1<smiles>COc1cc(-c2cc(=O)c3c(O)cc(O)cc3o2)cc(OC)c1O</smiles>
10<smiles>[R]C1OC(=O)C=C1c1ccc(O)c(O)c1</smiles><smiles>[R9]C1OC(=O)C=C1c1ccc(O)c(O)c1</smiles>

$4 \mathrm{R}=\mathrm{H}$

$4 a R=E t$

$4 \mathrm{~b} R=n-\mathrm{Pr}$

4c $R=i-P r$

$5 \mathrm{R}=\mathrm{OMe}$

$7 \mathrm{R}=\left(\mathrm{CH}_{2}\right)_{2} \mathrm{OH}$

$8 \mathrm{R}=\mathrm{COCH}_{2} \mathrm{OH}$

$3 \mathrm{R}=\mathrm{H}$

$9 \mathrm{R}=$ 竞 $\mathrm{OH}_{\mathrm{O}}^{\mathrm{O}}$.<smiles>[R]C1C[C@]2(I)OC(=O)C=C2C(C)(C)[C@@]1([R])C</smiles>

$11 \mathrm{R}_{1}=\alpha-\mathrm{OH}, \mathrm{R}_{2}=\beta-\mathrm{OH}$ $12 \mathrm{R}_{1}=\alpha-\mathrm{OH}, \mathrm{R}_{2}=\mathrm{H}$ $13 \mathrm{R}_{1}=\beta-\mathrm{OH}, \mathrm{R}_{2}=\mathrm{H}$

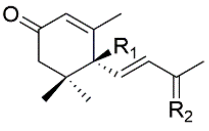

$15 \mathrm{R}_{1}=\mathrm{H}, \mathrm{R}_{2}=\beta-\mathrm{OH}$ $16 \mathrm{R}_{1}=\mathrm{H}, \mathrm{R}_{2}=\mathrm{O}$ $17 \mathrm{R}_{1}=\beta-\mathrm{OH}, \mathrm{R}_{2}=\mathrm{O}$<smiles>[R]c1cc(CCNC(=O)/C=C/c2ccc(O)c(OC)c2)ccc1O</smiles>

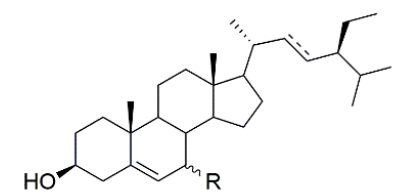<smiles>CCC(CC[C@@H](C)C1CCC2C3=CCC4CC(O)CCC4(C)C3CCC21C)C(C)C</smiles>

$18 \mathrm{R}=\mathrm{H}$ $19 \mathrm{R}=\mathrm{OMe}$<smiles>CCC(CC[C@@H](C)C1CCC2C3C=CC4CC(O)CC[C@]4(C)[C@H]3CCC21C)C(C)C</smiles>

26
$20 \mathrm{R}=\mathrm{H}$ $21 \mathrm{R}=\mathrm{H}, \Delta^{22}$ $22 \mathrm{R}=\mathrm{O}$ $23 \mathrm{R}=0, \Delta^{22}$ $24 \mathrm{R}=\beta-\mathrm{OH}$<smiles>C=C(CCC1CCC2C3=CCC4C(C)C(O)CCC4(C)C3(C)CCC12C)C(C)C</smiles>

27

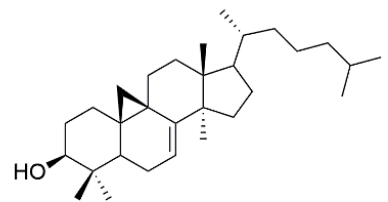

28

Figure 1. The chemical structures of compounds 1-28.

Table 1. ${ }^{1} \mathrm{H}$ - and ${ }^{13} \mathrm{C}-\mathrm{NMR}$ spectral data of compounds $\mathbf{1}$ and $\mathbf{2}$ ( $\delta$ in ppm, $J$ in $\mathrm{Hz}$ ).

\begin{tabular}{|c|c|c|c|c|}
\hline \multirow[b]{2}{*}{ No. } & \multicolumn{2}{|l|}{$1^{a}$} & \multicolumn{2}{|l|}{$2^{b}$} \\
\hline & $\delta_{\mathrm{H}}$ & $\delta_{\mathrm{C}}$ & $\delta_{\mathrm{H}}$ & $\delta_{\mathrm{C}}$ \\
\hline 2 & & 179.8 & & 171.0 \\
\hline 3 & $\begin{array}{l}2.86 \mathrm{dd}(17.4,8.6) \\
2.62 \mathrm{dd}(17.4,8.9)\end{array}$ & 36.9 & $6.49 \mathrm{~s}$ & 112.8 \\
\hline 4 & $3.68 \mathrm{~m}$ & 42.0 & & 162.8 \\
\hline 5 & $\begin{array}{l}4.62 \mathrm{t}(8.0) \\
4.20 \mathrm{t}(8.0)\end{array}$ & 76.2 & $7.40 \mathrm{~s}$ & 93.5 \\
\hline $1^{\prime}$ & & 133.0 & & 121.6 \\
\hline $2^{\prime}$ & $6.71 \mathrm{~d}(2.0)$ & 115.0 & $7.15 \mathrm{~d}(2.1)$ & 115.3 \\
\hline $3^{\prime}$ & & 146.9 & & 146.8 \\
\hline $4^{\prime}$ & & 145.9 & & 150.7 \\
\hline $5^{\prime}$ & $6.73 \mathrm{~d}(8.4)$ & 116.8 & $6.94 \mathrm{~d}(8.3)$ & 116.8 \\
\hline $6^{\prime}$ & $6.61 \mathrm{dd}(8.4,2.0)$ & 119.3 & $7.11 \mathrm{dd}(8.3,2.1)$ & 121.7 \\
\hline $1^{\prime \prime}$ & & & & 170.0 \\
\hline $2^{\prime \prime}$ & & & $2.15 \mathrm{~s}$ & 20.8 \\
\hline $\mathrm{OH}$ & & & $8.56 \mathrm{~s}$ & \\
\hline
\end{tabular}

${ }^{\mathrm{a}}$ Measured in methanol- $d_{4} \cdot{ }^{\mathrm{b}}$ Measured in acetone- $d_{6}$. 
Compound 2 was obtained as a colorless amorphous solid with $[\alpha]_{D}^{25}+2.5$, and its HRESIMS data determined the molecular formula as $\mathrm{C}_{12} \mathrm{H}_{10} \mathrm{O}_{6}\left(\mathrm{~m} / \mathrm{z} 249.0371\right.$, assigned as $\left.\mathrm{C}_{12} \mathrm{H}_{9} \mathrm{O}_{6}\right)$, indicating eight degrees of unsaturation. The IR spectrum displayed the presence of hydroxyl $\left(3470,3169 \mathrm{~cm}^{-1}\right)$, $\gamma$-lactone $\left(1757 \mathrm{~cm}^{-1}\right)$, ester $\left(1728 \mathrm{~cm}^{-1}\right)$, and aromatic $\left(1609,1516 \mathrm{~cm}^{-1}\right)$ functionalities.

The ${ }^{1} \mathrm{H}-\mathrm{NMR}$ spectrum (Table 1) displayed signals characteristic of the presence of two hydroxyl groups attached on the benzene ring $\left(\delta_{\mathrm{H}} 8.63\right.$, brs) as determined by $\mathrm{D}_{2} \mathrm{O}$ exchange experiment, a highly deshielded oxymethine $\left(\delta_{\mathrm{H}} 7.40, \mathrm{~s}, \mathrm{H}-5\right)$, a trisubstituted benzene ring indicated by an ABX-pattern for three aromatic protons $\left[\delta_{\mathrm{H}} 7.15(\mathrm{~d}, J=2.1 \mathrm{~Hz}), 7.11(\mathrm{dd}, J=8.3,2.1 \mathrm{~Hz})\right.$, and 6.94 $(\mathrm{d}, J=8.3 \mathrm{~Hz})]$, a conjugated olefinic proton $\left(\delta_{\mathrm{H}} 6.49, \mathrm{~s}, \mathrm{H}-3\right)$, and an acetyl group $\left(\delta_{\mathrm{H}} 2.15,3 \mathrm{H}, \mathrm{s}\right)$. Additionally, twelve carbon signals were displayed in the ${ }^{13} \mathrm{C}-\mathrm{NMR}$ spectrum. The assignments of two ortho-hydroxyl groups attached on the benzene ring were confirmed by two deshielded signals of aromatic carbons at $\delta_{C} 150.7$ and 146.8 . The IR peak at $v_{\max } 1757 \mathrm{~cm}^{-1}$ for $\gamma$-lactone functionality together with the carbon signals at $\delta_{\mathrm{C}} 171.0,162.8,112.8$, and 93.5 indicated the presence of the oxygenated unsaturated butenolide moiety. This moiety was also deduced from the HSQC correlations from $\mathrm{H}-3\left(\delta_{\mathrm{H}} 6.49 \mathrm{~s}\right)$ to $\mathrm{C}-3\left(\delta_{\mathrm{C}} 112.8\right)$ and from $\mathrm{H}-5\left(\delta_{\mathrm{H}} 7.40 \mathrm{~s}\right)$ to $\mathrm{C}-5\left(\delta_{\mathrm{C}} 93.5\right)$. The HMBC correlation from $\mathrm{H}-5\left(\delta_{\mathrm{H}} 7.40, \mathrm{~s}\right)$ to the acetyl carbon $\left(\delta_{\mathrm{C}} 170.0\right)$ indicated that the acetoxyl group was attached on the C-5 in butenolide moiety. The overall 1D and 2D NMR data suggested the structural similarities between 2 and bracteanolide A (4), except that the hydroxy group on C-5 in 4 was replaced by the $O$-acetyl group. This assignment was also confirmed by a highly deshielded oxymethine signal $\left(\delta_{\mathrm{H}} / \delta_{\mathrm{C}} 7.40 / 93.5\right)$. Compound 2 was consequently determined as new butenolide, named 5-O-acetyl bracteanolide A.

Compound 11 was obtained as a colorless oil with $[\alpha]_{D}^{25}+27.6$, and its high resolution electron ionization mass spectrometry (HREIMS) peak at $\mathrm{m} / \mathrm{z} 212.1043$ determined the molecular formula as $\mathrm{C}_{11} \mathrm{H}_{16} \mathrm{O}_{4}$, indicating four degrees of unsaturation. The IR spectrum displayed the presence of hydroxyl $\left(3406 \mathrm{~cm}^{-1}\right)$ and lactone $\left(1741 \mathrm{~cm}^{-1}\right)$ functionalities.

The ${ }^{1} \mathrm{H}-\mathrm{NMR}$ spectrum (Table 2) indicated the presence of an olefinic proton signal at $\delta_{\mathrm{H}} 5.78$ $(1 \mathrm{H}, \mathrm{s})$, two oxymethine signals at $\delta_{\mathrm{H}} 3.80$ and 3.04, a methylene signal at $\delta_{\mathrm{H}} 2.38$ and 1.43 , and three methyl signals at $\delta_{\mathrm{H}} 1.58,1.33$, and 1.18 (each $3 \mathrm{H}, \mathrm{s}$ ). ${ }^{13} \mathrm{C}-\mathrm{NMR}$ and DEPT experiments revealed the presence of 11 carbon signals, indicating a lactone carbon at $\delta_{C} 170.7$, a pair of conjugated carbon at $\delta_{C}$ 180.3 and 114.0, one oxygenated quaternary carbon at $\delta_{\mathrm{C}} 85.3$, two oxymethines at $\delta_{\mathrm{C}} 81.7$ and 67.9, a methylene at $\delta_{\mathrm{C}} 43.6$, and three methyls at $\delta_{\mathrm{C}} 25.7,25.2$, and 18.7 .

Table 2. ${ }^{1} \mathrm{H}$ - and ${ }^{13} \mathrm{C}-\mathrm{NMR}$ spectral data of compound 11 ( $\delta$ in ppm, $J$ in $\mathrm{Hz}$ ) in acetone- $d_{6}$.

\begin{tabular}{ccc}
\hline & \multicolumn{1}{c}{$\mathbf{1 1}$} & $\delta_{\mathbf{C}}$ \\
\hline No. & $\delta_{\mathbf{H}}$ & 39.6 \\
1 & & 81.7 \\
2 & $3.04 \mathrm{~d}(9.3)$ & 67.9 \\
3 & $3.80 \mathrm{ddd}(12.1,9.3,4.4)$ & 43.6 \\
4 & $1.43 \mathrm{t}(12.1) 2.38 \mathrm{dd}(12.1,4.4)$ & 85.3 \\
5 & & 180.3 \\
6 & $5.78 \mathrm{~s}$ & 114.0 \\
7 & & 170.7 \\
8 & $1.33 \mathrm{~s}$ & 25.7 \\
9 & $1.18 \mathrm{~s}$ & 18.7 \\
10 & $1.58 \mathrm{~s}$ & 25.5 \\
11 & &
\end{tabular}

An additional hydroxy group was assigned at $C-2\left(\delta_{C} 81.7\right)$ of $\mathbf{1 1}$ by comparing the NMR data of 12. The planar structure of $\mathbf{1 1}$ was confirmed by HMBC correlations shown in Figure 2. The di-axial orientations of H-2 and H-3 were deduced from the coupling constant of $9.3 \mathrm{~Hz}$ between them. The NOESY correlations between H-2 and Me-9; H-3 and Me-11; Me-10 and Me-11 established the 
relative configuration of $\mathbf{1 1}$. Thus, compound $\mathbf{1 1}$ was determined as a new apocarotenoid, named $2 \beta$-hydroxyepiloliolide.

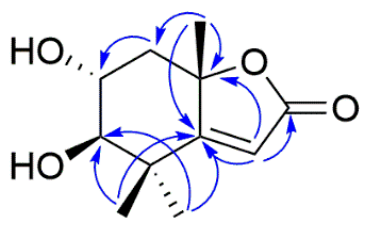

$\operatorname{HMBC}(\curvearrowright)$

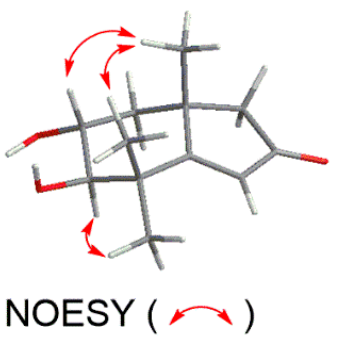

$\operatorname{NOESY}(\curvearrowleft)$

Figure 2. Selected HMBC and NOESY correlations of compound $\mathbf{1 1 .}$

In this study, the phytochemical investigation on the bioactive compounds from T. albiflora led to the isolation of 28 compounds including a butanolide rosmarinosin B (1) and four butenolides, 5-O-acetyl bracteanolide A (2), 4-(3',4'-dihydroxyphenyl)furan-2(5H)-one (3), bracteanolide A (4), and bracteanolide B (5). Among the isolates, the butanolide bracteanolide A (4) was highly abundant in this plant $(1.31 \mathrm{mg} / \mathrm{g}$ extract). It has been reported to exhibit inhibitory activity against LPS-activated NO production in RAW 264.7 cells by suppressing iNOS expression selectively [2], which is the potential target for the treatment of the inflammatory diseases caused by NO production. In order to screen the naturally anti-inflammatory butenolides and their related derivatives, four new butenolide derivatives 4a-4d were synthesized by modification from bracteanolide A (4) at C-4, focusing on changing the hydroxy group into alkoxy groups (Scheme 1). Then, the isolated compounds 2-8 and four new butenolide derivatives $\mathbf{4 a}-\mathbf{4} \mathbf{d}$ were evaluated for their preliminary anti-inflammatory activity against NO production in RAW 264.7 cells, a reliable indicator in investigating inflammatory activity [19].<smiles>O=C1C=C(c2ccc(O)c(O)c2)C(O)O1</smiles>

4

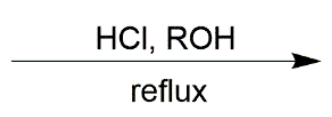

4a $\mathrm{R}=\mathrm{Et}$
4b $\mathrm{R}=n-\mathrm{Pr}$
4c $\mathrm{R}=i-\mathrm{Pr}$
4d $\mathrm{R}=n-\mathrm{Bu}$

Scheme 1. Synthesis of butenolide derivatives $\mathbf{4 a}-\mathbf{4 d}$.

All compounds evaluated displayed lower anti-inflammatory activity than the positive control dexamethasone (Table 3), which has been reported to decrease iNOS-dependent NO production [20]. Dexamethasone is a highly effective anti-inflammatory and immunosuppressant corticosteroid. Unfortunately, the long-term use may cause serious systemic side effects, ranging from weight gain, diabetes, hypertension, immunosuppression, psychological disturbances, fragile skin, muscle weakness, osteoporosis, and Cushing's syndrome [21].

As shown in Table 3 and Figure S22, compounds 4, 4b, 4d, 6, and 7 showed inhibitory potential against NO production, which was not associated with their cytotoxicity against RAW 264.7 cells (Figure S23). The results suggested that the disappearance of the hydroxy group (3) or the presence of methyl (5), ethyl (4a), $i$-propyl (4c), and acetyl groups (2) resulted in a decreased activity; the presence of $n$-propyl group did not affect the activity. The data also revealed that the catechol group might have contributed to the activity even if the result of compound 8 was unsatisfactory (the $\mathrm{IC}_{50}$ value was above $50 \mu \mathrm{g} / \mathrm{mL}$ ). Among compounds evaluated, compound 4d with an $n$-butyl group showed enhanced 
anti-inflammatory activity ( $\mathrm{IC}_{50}$ value of $4.32 \pm 0.09 \mu \mathrm{g} / \mathrm{mL}$ ) compared to the original compound (Table 3).

Table 3. Inhibitory effect of compounds $\mathbf{2 - 8}$ and $\mathbf{4 a} \mathbf{- 4 d}$ against NO production in LPS-stimulated RAW 264.7 cells.

\begin{tabular}{cc}
\hline Compounds & $\mathrm{IC}_{\mathbf{5 0}}(\boldsymbol{\mu g} / \mathrm{mL})$ \\
\hline $\mathbf{2}$ & $37.48 \pm 1.38$ \\
$\mathbf{3}$ & $18.75 \pm 3.37$ \\
$\mathbf{4}$ & $10.11 \pm 0.35$ \\
$\mathbf{4 a}$ & $21.77 \pm 1.67$ \\
$\mathbf{4 b}$ & $9.97 \pm 0.32$ \\
$\mathbf{4 c}$ & $22.74 \pm 3.56$ \\
$\mathbf{4 d}$ & $4.32 \pm 0.09$ \\
$\mathbf{5}$ & $16.51 \pm 0.81$ \\
$\mathbf{6}$ & $8.93 \pm 1.06$ \\
$\mathbf{7}$ & $5.76 \pm 0.11$ \\
$\mathbf{8}$ & $>50$ \\
Dexamethasone & $0.97 \pm 0.04$ \\
\hline
\end{tabular}

\section{Materials and Methods}

\subsection{General}

Optical rotations were measured with a DIP-1000 Polarimeter (JASCO, Tokyo, Japan). UV spectra

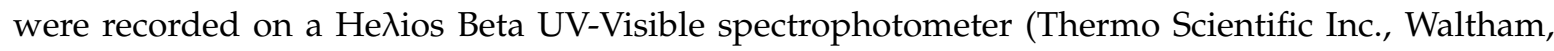
MA, USA). Infrared spectra were acquired on a Nicolet MAGNA-IR 500 spectrophotometer (Thermo Scientific Inc., Waltham, MA, USA). The NMR experiments were performed on DMX-400 and DMX-500 MHz NMR spectrometers (Bruker, Bremen, Germany). HREIMS and HRESIMS spectra were generated with SX-102A (JEOL, Tokyo, Japan) and maXis impact mass spectrometers (Bruker Daltonics, Bremen, Germany), respectively. Column chromatography was performed on Silica gel 60 (40-63 $\mu \mathrm{m}$, Merck, Darmstadt, Germany), high performance liquid chromatography (HPLC) was performed using Keystone Spherisorb silica $(5 \mu \mathrm{m}, 250 \times 10 \mathrm{~mm})$, and thin-layer chromatography (TLC) was performed on silica gel 60 F254 plates ( $200 \mu \mathrm{m}$, Merck).

\subsection{Plant Material}

The greenhouse-grown plant material was obtained from Dr. T.-F.K. (Department of Post-Baccalaureate Veterinary Medicine, Asia University). A voucher specimen (TAIF-PLANT-199332) has been retained at the Herbarium of Taiwan Forestry Research Institute, Taipei, Taiwan.

\subsection{Extraction and Isolation}

Air-dried whole plant of T. albiflora $(14.9 \mathrm{~kg})$ was extracted twice with methanol $(40 \mathrm{~L})$ at room temperature for 7 days, and concentrated under vacuum. The methanol extract $(1.5 \mathrm{~kg})$ taken up in distilled water was fractionated successively with ethyl acetate and $n$-butanol to yield the corresponding solvent-soluble fractions. The ethyl acetate-soluble fraction $(232.7 \mathrm{~g})$ was subjected to silica gel column chromatography ( $2.0 \mathrm{~kg}, 70-230$ mesh) using a gradient solvent system ( $n$-hexane/ethyl acetate/methanol) as eluant to afford 10 fractions. Fr. 3 (35.2 g) was reseparated by silica gel column chromatography ( $n$-hexane/acetone $=95 / 5)$ followed by semi-preparative normal phase HPLC to give compounds 25 (10.7 mg), $27(7.6 \mathrm{mg})$, and $28(7.4 \mathrm{mg})$. Fr. 4 (24.6 g) was reseparated by silica gel column chromatography (dichloromethane/acetone $=95 / 5$ ) and recrystallization to obtain compounds 20/21 (740.2 mg) and $26(8.8 \mathrm{mg})$. Fr. $5(9.0 \mathrm{~g})$ was reseparated by silica gel column chromatography using a gradient solvent system (dichloromethane/ethyl acetate) to afford 10 fractions. Fr. 5-2 was purified by normal phase HPLC (dichloromethane/acetone $=80 / 20)$ to give compounds $10(8.1 \mathrm{mg}), \mathbf{1 2}(57.9 \mathrm{mg})$, 
$16(9.0 \mathrm{mg})$, and $17(11.0 \mathrm{mg})$. Fr. 5-4 was purified by normal phase HPLC (dichloromethane/acetone = $80 / 20)$ to obtain compounds $\mathbf{1 1}(4.7 \mathrm{mg}), \mathbf{1 4}(13.0 \mathrm{mg})$, and 22/23 (44.1 $\mathrm{mg})$. Fr. 5-5 was purified by normal phase HPLC $(n$-hexane/acetone $=80 / 20)$ to obtain compound $24(13.6 \mathrm{mg})$. Fr. 5-7 purified by normal phase HPLC (dichloromethane/ethyl acetate $=65 / 35)$ to obtain compound $9(27.4 \mathrm{mg})$. Fr. $6(18.4 \mathrm{~g})$ was reseparated by silica gel column chromatography a gradient solvent system (dichloromethane/ethyl acetate) to afford 12 fractions. Fr. 6-2 was purified by normal phase HPLC (dichloromethane/ethyl acetate $=67 / 33)$ to obtain compounds $6(8.8 \mathrm{mg})$ and $\mathbf{1 3}(30.1 \mathrm{mg})$. Fr. 6-3 was purified by normal phase HPLC (dichloromethane/ethyl acetate $=50 / 50)$ to obtain compound $15(9.0 \mathrm{mg})$. Fr. 6-6 was purified by normal phase HPLC ( $n$-hexane/acetone $=75 / 25)$ to obtain compounds $\mathbf{1}(5.1 \mathrm{mg})$ and $\mathbf{2}(10.3 \mathrm{mg})$. Fr. 6-7 was purified by normal phase HPLC ( $n$-hexane/ethyl acetate $=30 / 70)$ to obtain compounds $3(8.8 \mathrm{mg})$, 4 (1958.6 mg), and 5 (30.1 mg). Fr. 6-8 was purified by normal phase HPLC (dichloromethane/acetone $=75 / 25)$ to obtain compounds $7(13.1 \mathrm{mg})$ and $8(8.0 \mathrm{mg})$. Fr. $6-8$ was purified by normal phase HPLC (dichloromethane/acetone $=70 / 30)$ to obtain compounds $18(8.9 \mathrm{mg})$ and $19(7.1 \mathrm{mg})$.

Rosmarinosin B (1): Colorless amorphous solid; $[\alpha]_{D}^{25}-13.5$ (c 0.1, MeOH); UV (MeOH) $\lambda_{\max }(\log \varepsilon): 283$ (2.54) nm; IR (KBr) $v_{\max } 3312,2918,2851,1759,1607,1526,1449,1375,1285,1188,1117$, and $1015 \mathrm{~cm}^{-1}$; HRESIMS $m / z 217.0464[\mathrm{M}+\mathrm{Na}]^{+}\left(\mathrm{C}_{10} \mathrm{H}_{10} \mathrm{O}_{4} \mathrm{Na}\right) ;{ }^{1} \mathrm{H}$ - and ${ }^{13} \mathrm{C}-\mathrm{NMR}$ : see Table 1.

5-O-Acetylbracteanolide A (2): Colorless amorphous solid $[\alpha]_{D}^{25}+2.5$ (c $\left.0.1, \mathrm{MeOH}\right) ; \mathrm{UV}(\mathrm{MeOH}) \lambda_{\max }$ (log ع): 217 (4.08), 249 (4.02), 334.6 (4.19) nm; IR (KBr) $v_{\max }$ 3470, 3169, 2961, 2924, 1757, 1728, 1609, $1516,1302,1285,1223,1198,1177,1032$, and $989 \mathrm{~cm}^{-1}$; HRESIMS $\mathrm{m} / \mathrm{z} 249.0371\left[\mathrm{M}-\mathrm{H}^{-}\left(\mathrm{C}_{12} \mathrm{H}_{9} \mathrm{O}_{6}\right) ;{ }^{1} \mathrm{H}-\right.$ and ${ }^{13} \mathrm{C}$-NMR: see Table 1.

2 $\beta$-Hydroxyisololiolide (11): Colorless oil; $[\alpha]_{D}^{25}+27.6$ (c 0.27, MeOH); UV (MeOH) $\lambda_{\max }(\log \varepsilon)$ : 212 (3.94), 272 (2.79) nm; IR (KBr) $v_{\max } 3406,2925,2873,1742,1629,1460,1383,1291,1260,1050,984$, and $938 \mathrm{~cm}^{-1}$; HREIMS $m / z 212.1043[\mathrm{M}]^{+}\left(\mathrm{C}_{11} \mathrm{H}_{16} \mathrm{O}_{4}\right) ;{ }^{1} \mathrm{H}$ - and ${ }^{13} \mathrm{C}-\mathrm{NMR}$ : see Table 2.

\subsection{Preparation of Butenolide Derivatives $\mathbf{4 a}-\mathbf{4 d}$}

Bracteanolide A $(20 \mathrm{mg})$ was dissolved in the corresponding alcohol $(10 \mathrm{~mL})$. Concentrated hydrochloric acid ( 3 drops) was added and the solution was refluxed and stirred for $12 \mathrm{~h}$. The solvent was evaporated under vacuum to produce a yellow residue that was diluted with distilled water and fractionated twice with dichloromethane. The organic extracts were combined and dried over magnesium sulfate to give butenolide derivatives $\mathbf{4 a}-\mathbf{4 d}$, in approximately $70 \%$ yield.

5-O-Ethyl bracteanolide A (4a): Yield 73\%; IR (KBr) $v_{\max } 3368,3098,2974,1728,1605,1512,1373,1342$, 1300, 1281, 1200, 1177, 1115, 1015, 972, and $945 \mathrm{~cm}^{-1} ;{ }^{1} \mathrm{H}-\mathrm{NMR}$ (acetone- $\left.d_{6}, 400 \mathrm{MHz}\right): \delta_{\mathrm{H}} 7.28(\mathrm{~d}, 1 \mathrm{H}$, $J=2.1 \mathrm{~Hz}), 7.21(\mathrm{dd}, 1 \mathrm{H}, J=8.3,2.1 \mathrm{~Hz}), 6.92(\mathrm{~d}, 1 \mathrm{H}, J=8.3 \mathrm{~Hz}), 6.38(\mathrm{~s}, 1 \mathrm{H}), 6.36(\mathrm{~s}, 1 \mathrm{H}), 3.84(\mathrm{~m}, 2 \mathrm{H})$, $1.24(\mathrm{t}, 3 \mathrm{H}, J=7.1 \mathrm{~Hz}) ;{ }^{13} \mathrm{C}-\mathrm{NMR}: \delta_{\mathrm{C}} 170.5,161.7,148.8,145.4,121.7,120.9,115.5,114.7,112.2,102.1$, $64.2,14.5$.

5-O-n-Propyl bracteanolide A (4b): Yield 70\%; IR (KBr) $v_{\max } 3472,3167,2970,2878,1713,1605,1512,1408$, $1342,1300,1285,1200,1177,1123,1030,964$, and $949 \mathrm{~cm}^{-1} ;{ }^{1} \mathrm{H}-\mathrm{NMR}$ (acetone- $\left.d_{6}, 400 \mathrm{MHz}\right): \delta_{\mathrm{H}} 7.28$ $(\mathrm{d}, 1 \mathrm{H}, J=1.9 \mathrm{~Hz}), 7.21(\mathrm{dd}, 1 \mathrm{H}, J=8.3,1.9 \mathrm{~Hz}), 6.93(\mathrm{~d}, 1 \mathrm{H}, J=8.3 \mathrm{~Hz}), 6.38(\mathrm{~s}, 1 \mathrm{H}), 6.37(\mathrm{~s}, 1 \mathrm{H}), 3.77$ $(\mathrm{t}, 2 \mathrm{H}, J=7.1 \mathrm{~Hz}), 1.63(\mathrm{tq}, 2 \mathrm{H}, J=7.0 \mathrm{~Hz}), 0.92(\mathrm{t}, 3 \mathrm{H}, J=7.0 \mathrm{~Hz}) ;{ }^{13} \mathrm{C}$ NMR: $\delta_{\mathrm{C}} 170.5,161.7,148.7$, $145.4,121.7,121.0,115.5,114.8,112.2,102.3,70.1,22.6,9.9$.

5-O-i-Propyl bracteanolide A (4c): Yield 67\%; IR (KBr) $v_{\max } 3472,3159,2978,2920,2808,1713,1605,1512$, $1408,1381,1323,1342,1300,1281,1196,1150,1126,1030,961$, and $922 \mathrm{~cm}^{-1} ;{ }^{1} \mathrm{H}-\mathrm{NMR}$ (acetone- $d_{6}$, $400 \mathrm{MHz}): \delta_{\mathrm{H}} 7.26(\mathrm{~d}, 1 \mathrm{H}, J=2.1 \mathrm{~Hz}), 7.19(\mathrm{dd}, 1 \mathrm{H}, J=8.3,2.1 \mathrm{~Hz}), 6.92(\mathrm{~d}, 1 \mathrm{H}, J=8.3 \mathrm{~Hz}), 6.44(\mathrm{~s}, 1 \mathrm{H})$, $6.33(\mathrm{~s}, 1 \mathrm{H}), 4.22(\mathrm{~m}, 2 \mathrm{H}), 1.33(\mathrm{t}, 3 \mathrm{H}, J=6.1 \mathrm{~Hz}), 1.23(\mathrm{t}, 3 \mathrm{H}, J=6.1 \mathrm{~Hz}) ;{ }^{13} \mathrm{C}$ NMR: $\delta_{\mathrm{C}} 170.6,162.1$, 148.7, 145.3, 121.8, 120.9, 115.5, 114.8, 112.1, 101.4, 72.8, 22.8, 21.6.

5-O-n-Butyl bracteanolide A (4d): Yield 69\%; IR (KBr) $v_{\max } 3476,3171,2963,2936,2874,1732,1605,1512$, $1412,1373,1342,1300,1200,1126,1030,972,941$, and $929 \mathrm{~cm}^{-1} ;{ }^{1} \mathrm{H}-\mathrm{NMR}$ (acetone- $d_{6}, 400 \mathrm{MHz}$ ): $\delta_{\mathrm{H}}$ 
$7.27(\mathrm{~d}, 1 \mathrm{H}, J=1.9 \mathrm{~Hz}), 7.21(\mathrm{dd}, 1 \mathrm{H}, J=8.3,1.9 \mathrm{~Hz}), 6.92(\mathrm{~d}, 1 \mathrm{H}, J=8.3 \mathrm{~Hz}), 6.38(\mathrm{~s}, 1 \mathrm{H}), 6.36(\mathrm{~s}, 1 \mathrm{H})$, $3.78(\mathrm{~m}, 2 \mathrm{H}), 1.60(\mathrm{dq}, 2 \mathrm{H}, J=6.6 \mathrm{~Hz}), 1.37(\mathrm{tq}, 2 \mathrm{H}, J=6.2 \mathrm{~Hz}), 0.89(\mathrm{t}, 3 \mathrm{H}, J=7.4 \mathrm{~Hz}) ;{ }^{13} \mathrm{C}$ NMR: $\delta_{\mathrm{C}}$ $170.5,161.7,148.8,145.4,121.6,120.9,115.5,114.7,112.2,102.3,68.1,31.4,18.9,13.1$.

\subsection{Cell Culture}

A murine macrophage cell line RAW264.7 (BCRC No. 60001) was obtained from the Bioresources Collection and Research Center of the Food Industry Research and Development Institute (Hsinchu, Taiwan). Cells were maintained in Dulbecco's Modified Eagle Medium (DMEM, Sigma, St. Louis, MO, USA) supplemented with $10 \%$ fetal bovine serum (FBS, Sigma) in an incubator containing $5 \%$ $\mathrm{CO}_{2}$ at $37{ }^{\circ} \mathrm{C}$ and subcultured every 3 days using $0.05 \%$ trypsin- $0.02 \%$ EDTA in $\mathrm{Ca}^{2+}-, \mathrm{Mg}^{2+}$-free phosphate-buffered saline (DPBS).

\subsection{Cell Viability}

Raw 264.7 cells $\left(5 \times 10^{4}\right.$ cells/well) were seeded into 96-well plates and incubated for $24 \mathrm{~h}$. Then, cells were treated with different concentrations of samples in the presence of $100 \mathrm{ng} / \mathrm{mL}$ LPS. After incubation overnight, the cells were washed twice with DPBS and incubated with $100 \mu \mathrm{L}$ MTT $(0.5 \mathrm{mg} / \mathrm{mL})$ for $3 \mathrm{~h}$. The medium was removed, and MTT formazan was dissolved by $100 \mu \mathrm{L}$ dimethyl sulfoxide (DMSO). Then, absorbance at $570 \mathrm{~nm}$ was read using a microplate reader.

\subsection{Measurement of Nitric Oxide/Nitrite}

NO production was indirectly measured by determining the nitrite levels in the cultured medium using a colorimetric assay based on the Griess reaction. Cells were treated with different concentrations of samples in the presence of LPS $(100 \mathrm{ng} / \mathrm{mL})$ and incubated for $24 \mathrm{~h}$. Then, each supernatant $(100 \mu \mathrm{L})$ was mixed with the same volume of Griess reagent ( $1 \%$ sulfanilamide, $0.1 \%$ naphthylethylenediamine dihydrochloride and 5\% phosphoric acid) and incubated for $5 \mathrm{~min}$, and the absorbance at $540 \mathrm{~nm}$ was measured using a microplate reader.

\section{Conclusions}

In summary, phytochemical investigation of the whole plant of Tradescantia albiflora Kunth has led to the isolation and characterization of a butanolide, rosmarinosin B (1), that was isolated from natural sources for the first time, a new butenolide, 5-O-acetyl bracteanolide A (2), and a new apocarotenoid $2 \beta$-hydroxyisololiolide (11), together with 25 known compounds (compounds 3-10 and 12-28). The isolated compounds $\mathbf{2 - 8}$ and four new synthetic butenolide derivatives $\mathbf{4 a}-\mathbf{4 d}$, which were synthesized from bracteanolide A (4), were evaluated for their preliminary anti-inflammatory activity against LPS-stimulated NO production in RAW 264.7 cells. Among them, the new synthetic butenolide derivative $n$-butyl bracteanolide A (4d) exhibited better NO inhibitory activity than the original compound bracteanolide A (4).

Supplementary Materials: Supplementary Materials related to this article can be found online.

Author Contributions: Conceptualization, T.-F.K. and Y.-H.K.; methodology, Y.-H.K. and G.-J.H.; investigation, P.-C.T., H.-C.T., and Y.-C.L.; resources, G.-J.H. and Y.-H.K.; writing-original draft preparation, P.-C.T. and Y.-C.L.; writing-review and editing, P.-C.T., Y.-C.L., and Y.-H.K.; supervision, T.-L.L. and Y.-H.K.

Funding: This work was financially supported by Taiwan Ministry of Health and Welfare Clinical Trial Center (MOHW107-TDU-B-212-123004) and "Chinese Medicine Research Center, China Medical University" from The Featured Areas Research Center Program within the framework of the Higher Education Sprout Project by the Ministry of Education (MOE) in Taiwan (CMRC-CHM-4).

Conflicts of Interest: The authors declare no conflict of interest. 


\section{References}

1. Wang, W.L.; Sheu, S.Y.; Huang, W.D.; Chuang, Y.L.; Tseng, H.C.; Hwang, T.S.; Fu, Y.T.; Kuo, Y.H.; Yao, C.H.; Kuo, T.F. Phytochemicals from Tradescantia albiflora Kunth extracts reduce serum uric acid levels in oxonate-induced rats. Pharm. Mag. 2016, 12, S223-S227.

2. Wang, G.J.; Chen, S.M.; Chen, W.C.; Chang, Y.M.; Lee, T.H. Selective inducible nitric oxide synthase suppression by new bracteanolides from Murdannia bracteata. J. Ethnopharmacol. 2007, 112, 221-227. [CrossRef] [PubMed]

3. Vo, Q.H.; Nguyen, P.H.; Zhao, B.T.; Ali, M.Y.; Choi, J.S.; Min, B.S.; Nguyen, T.H.; Woo, M.H. Protein tyrosine phosphatase 1B (PTP1B) inhibitory constituents from the aerial parts of Tradescantia spathacea Sw. Fitoterapia 2015, 103, 113-121. [CrossRef] [PubMed]

4. Yuan, X.; Wen, H.; Cui, Y.; Fan, M.; Liu, Z.; Mei, L.; Shao, Y.; Wang, Y.; Tao, Y. Phenolics from Lagotis brevituba Maxim. Nat. Prod. Res. 2017, 31, 362-366. [CrossRef] [PubMed]

5. Ziosi, P.; Paolucci, C.; Santarelli, F.; Tabanelli, T.; Passeri, S.; Cavani, F.; Righi, P. A two-step process for the synthesis of hydroxytyrosol. ChemSusChem. 2018, 11, 2202-2210. [CrossRef]

6. Govindan, B.; Johnson, A.J.; Viswanathan, G.; Ramaswamy, V.; Koshy, K.C.; Baby, S. Secondary metabolites from the unique bamboo, Melocanna baccifera. Nat. Prod. Res. 2019, 33, 122-125. [CrossRef]

7. Kimura, J.; Maki, N. New loliolide derivatives from the brown alga Undaria pinnatifida. J. Nat. Prod. 2002, 65, 57-58. [CrossRef]

8. De Marino, S.; Borbone, N.; Gala, F.; Zollo, F.; Fico, G.; Pagiotti, R.; Iorizzi, M. New constituents of sweet Capsicum annuum L. fruits and evaluation of their biological activity. J. Agric. Food Chem. 2006, 54, 7508-7516. [CrossRef]

9. Yamano, Y.; Sasaki, H.; Wada, A. Versatile amine-promoted mild methanolysis of 3,5-dinitrobenzoates and its application to the synthesis of colorado potato beetle pheromone. Chem. Pharm. Bull. 2017, 65, 940-944. [CrossRef]

10. Xiong, H.P.; Mi, J.L.; Le, J.M.; Wu, Z.J.; Chen, W.S. Chemical constituents of Ampelopsis japonica. Chem. Nat. Compd. 2017, 53, 791-793. [CrossRef]

11. Clemente-Tejeda, D.; Bermejo, F.A. Oxidation of alkenes with non-heme iron complexes: Suitability as an organic synthetic method. Tetrahedron 2014, 70, 9381-9386. [CrossRef]

12. Jia, X.; Yang, D.; Yang, Y.; Xie, H. Carotenoid-derived flavor precursors from Averrhoa carambola fresh fruit. Molecules 2019, 24, 256. [CrossRef] [PubMed]

13. Jiang, M.; Zhang, W.; Yang, X.; Xiu, F.; Xu, H.; Ying, X.; Stien, D. An isoindole alkaloid from Portulaca oleracea L. Nat. Prod. Res. 2018, 32, 2431-2436. [CrossRef] [PubMed]

14. Badreddine, A.; Karym el, M.; Zarrouk, A.; Nury, T.; El Kharrassi, Y.; Nasser, B.; Cherkaoui Malki, M.; Lizard, G.; Samadi, M. An expeditious synthesis of spinasterol and schottenol, two phytosterols present in argan oil and in cactus pear seed oil, and evaluation of their biological activities on cells of the central nervous system. Steroids 2015, 99, 119-124. [CrossRef] [PubMed]

15. Zhu, Y.; Soroka, D.; Sang, S. Oxyphytosterols as active ingredients in wheat bran suppress human colon cancer cell growth: Identification, chemical synthesis, and biological evaluation. J. Agric. Food Chem. 2015, 63, 2264-2276. [CrossRef] [PubMed]

16. Wang, Y.; Xu, L.; Ren, W.; Zhao, D.; Zhu, Y.; Wu, X. Bioactive metabolites from Chaetomium globosum L18, an endophytic fungus in the medicinal plant Curcuma wenyujin. Phytomedicine 2012, 19, 364-368. [CrossRef] [PubMed]

17. Wu, Z.H.; Liu, T.; Gu, C.X.; Shao, C.L.; Zhou, J.; Wang, C.Y. Steroids and triterpenoids from the brown alga Kjellmaniella crassifolia. Chem. Nat. Compd. 2012, 48, 158-160. [CrossRef]

18. Jeong, G.H.; Cho, J.H.; Jo, C.; Lee, S.; Lee, S.S.; Bai, H.W.; Chung, B.Y.; Kim, T.H. Gamma irradiation-assisted degradation of rosmarinic acid and evaluation of structures and anti-adipogenic properties. Food Chem. 2018, 258, 181-188. [CrossRef]

19. Yang, C.S.; Chen, J.J.; Huang, H.C.; Huang, G.J.; Wang, S.Y.; Sung, P.J.; Cheng, M.J.; Wu, M.D.; Kuo, Y.H. New Benzenoid Derivatives and Other Constituents from Lawsonia inermis with Inhibitory Activity against NO Production. Molecules 2017, 22, 936. [CrossRef]

20. Korhonen, R.; Lahti, A.; Hamalainen, M.; Kankaanranta, H.; Moilanen, E. Dexamethasone inhibits inducible nitric-oxide synthase expression and nitric oxide production by destabilizing mRNA in lipopolysaccharide-treated macrophages. Mol. Pharm. 2002, 62, 698-704. [CrossRef] 
21. Bordag, N.; Klie, S.; Jurchott, K.; Vierheller, J.; Schiewe, H.; Albrecht, V.; Tonn, J.C.; Schwartz, C.; Schichor, C.; Selbig, J. Glucocorticoid (dexamethasone)-induced metabolome changes in healthy males suggest prediction of response and side effects. Sci. Rep. 2015, 5, 15954. [CrossRef] [PubMed]

Sample Availability: Samples of the compounds 1-10 and 18-28 are available from the authors.

(C) 2019 by the authors. Licensee MDPI, Basel, Switzerland. This article is an open access article distributed under the terms and conditions of the Creative Commons Attribution (CC BY) license (http://creativecommons.org/licenses/by/4.0/). 